Research Article

\title{
Socio-economic analysis of open pollinated improved and hybrid maize production in Sindhupalchok district of Nepal
}

\author{
Grace Tiwari ${ }^{1 *}$, Chandan K.C. ${ }^{2}$, Praseed Thapa ${ }^{1}$ and Astha Shrestha ${ }^{1}$ \\ ${ }^{1}$ Agriculture and Forestry University, Rampur, Chitwan, Nepal \\ ${ }^{2}$ Institute of Agriculture and Animal Science, Tribhuvan University, Kritipur, Nepal \\ *Correspondence: grace.tiwari9@gmail.com \\ *ORCID: https://orcid.org/0000-0002-6076-3312 \\ Received: September 07, 2020; Accepted: November 17, 2020; Published: January 01, 2021
}

(C) Copyright: Tiwari et al. (2021).

(c) (1) (8)

This work is licensed under a Creative Commons Attribution-Non Commercial 4.0 International License.

\begin{abstract}
The study was conducted from April to June, 2020 for comparative analysis of socioeconomic factors and profitability between Open Pollinated Improved (OPI) varieties and Hybrid varieties on maize production in Sindhupalchok district of Nepal. A structured questionnaire was administered to 80 randomly selected households i.e. $48 \mathrm{HHs}$ cultivated OPI and $32 \mathrm{HHs}$ cultivated hybrid maize varieties. Descriptive statistics, unpaired t-test, multiple linear regressions and indexing were used for data analysis using statistical tools- SPSS version 25 and MS-Excel. Linear regression model revealed that area under maize (5\% level), education (5\% level), age of household head (1\% level), training (1\% level), access to credit (5\% level) and choice of seed (1\% level) significantly influenced maize production. In addition, unpaired t-test revealed that the productivity of hybrid maize varieties was significantly higher (1\% level) than OPI varieties. Fall Armyworm infestation was found to more severe in OPI varieties (5\% level) than hybrid. Furthermore, B: C ratio of hybrid varieties (1.59) indicated hybrid maize to be more profitable than OPI (1\% level). However, the total cost of cultivation along with the cost of seed per hectare of OPI was found to be lower than hybrid varieties (1\% level) thereby significantly increasing the area under maize production for OPI varieties (1\% level). Indexing identified- lack of availability of quality seeds and fertilizers $(\mathrm{I}=0.78)$ as the major problem associated with maize production. Ensuring access to quality seeds and fertilizer at subsidy, mechanization and efficient extension services focused on development of affordable hybrid maize varieties or high yielding OPI and its adoption among the farmers in order to increase maize productivity is recommended.
\end{abstract}

Keywords: profitability, maize productivity, linear regression, socio-economic analysis

Correct citation: Tiwari, G., K.C., C., Thapa, P., \& Shrestha, A. (2021). Socio-economic analysis of open pollinated improved and hybrid maize production in Sindhupalchok district of Nepal. Journal of Agriculture and Natural Resources, 4(1), 130-139. DOI: https://doi.org/10.3126/janr.v4i1.33246

\section{INTRODUCTION}

Out of all major cereals in Nepal, maize ranks second in terms of both area and production after rice. It is grown in three distinct agro-climatic regions within Nepal; the Terai (below 900m), the hills (900-1800m) and the mountains (above 1800m) (Paudyal et al., 2001). Maize occupies $78 \%$ area out of the total cultivated land in hills. Two third of the maize produced in hills of Nepal is used directly by the farmers either for household consumption or livestock production. 
Journal of Agriculture and Natural Resources (2021) 4(1): 130-139

ISSN: 2661-6270 (Print), ISSN: 2661-6289 (Online)

DOI: https://doi.org/10.3126/janr.v4i1.33246

The area of maize production in Nepal is 956,447 ha and the total production is $2,713,635$ Metric ton (mt) with an annual yield of $2.84 \mathrm{t} / \mathrm{ha}$ (MOALD, 2017). In Sindhupalchok, maize is cultivated in 24,687 ha of area, with $69,445 \mathrm{mt}$ of production and productivity of $2.81 \mathrm{t} / \mathrm{ha}$ which is fairly equals to the national productivity of maize (MOALD, 2017). The productivity of maize in the country is almost stagnant, while the demand for maize is increasing in Nepal because of the emerging poultry industry (Dhakal et al., 2015). It is reported that the demand for maize has been growing by $5 \%$ over the last decade (Sapkota \& Pokhrel, 2013).

Various factors are responsible for the constant productivity of maize crop in Nepal. The existing gap between maize production and demand is due to various socio-economic and technological factors (Sapkota \& Pokhrel, 2013). Socioeconomic characteristics of farmers are important factors influencing maize production. The most important variables included in this category are age, education, household size, farm size, membership, training and extension contact (Adhikari et al., 2018). Likewise, age of household head, ethnicity, credit accessibility, cooperative involvement, extension visit, training, formal sector seed availability were found important factors for the adoption of modern variety of maize (Upadhyay et al., 2018). The main objective of this study was to determine the significant relationship between farmers' socioeconomic characteristics and maize output. While making a production decision, farmers consider costs of production and yield which ultimately affect the rate of adoption and sustainability of any crop. So, the profitability study between OPI and hybrid maize farming gives valuable information regarding production decision and farm management. Open pollinated improved varieties of maize including Poshilo Makai-1, Rampur composite, Deuti, Manakamana and hybrid such as CP 808, Khumal hybrid-2 were used by the farmers of Sindhupalchok. Thus, this study aims to compare the profitability and socioeconomic factors between OPI and hybrid varieties that influence maize production. The study is very important for policy makers, researchers and extension agents so that they can make appropriate planning and strategy to increase maize productivity in central mid-hills of Nepal.

\section{METHODOLOGY}

\section{Study area, sample size and data collection technique}

The data used in this study was based on the farm level study of maize farmers in Sindhupalchok district, Bagmati province of Nepal. The main crops cultivated in these districts are; paddy, maize, vegetables and potato. Sindhupalchok is the major maize production district in central mid-hills, thus, the Government of Nepal established Project Implementation Unit under Prime Minister Agriculture Modernization Project (PM-AMP) considering Sindhupalchok as Maize Zone. Four command areas under PM-AMP Maize zone of Sindhupalchok- Chautara Sangachokgadhi, Balefi, Indrawati and Melamchi were selected for the study. There were around 400 registered farmers from the project implementation unit. Raosoft calculator was used to determine the sample population at $95 \%$ confidence interval and $10 \%$ margin of error. A total of 80 households were surveyed from April to June, 2020 for the study. 48 OPI seed users and 32 hybrid seed users were selected simple randomly from the list of maize growers in the selected villages. A comprehensive and structured questionnaire was used to collect data from maize growers. Face to face interview as well as phone call interview was conducted due to the covid19 pandemic with 80 farmers to collect information on socio-economic information, farming practices, cost of cultivation, return from the maize crop and problems associated with maize production. In addition, key informants and focus 
Journal of Agriculture and Natural Resources (2021) 4(1): 130-139

ISSN: 2661-6270 (Print), ISSN: 2661-6289 (Online)

DOI: https://doi.org/10.3126/janr.v4i1.33246

group discussions were conducted in each location. Secondary data were collected from relevant publication of government offices such as Ministry of Agricultural and Livestock Development (MOALD), National Maize Research Program (NMRP), Central Bureau of Statistics (CBS), National Planning Commission (NPC) and so on.

\section{Data analysis}

The collected data were then coded and entered. Descriptive statistics, unpaired t-test, multiple linear regression model and indexing were used for data analysis using statistical tools- SPSS version 25 and MS-Excel.

\section{Multiple Regression Model}

The multiple linear regression model was used to estimate the socioeconomic factors that influenced overall maize production (i.e. both OPI and hybrid varieties combined). Dependent variables such as Maize area, farm size, education of $\mathrm{HHH}$, age of $\mathrm{HHH}$, family size, training, membership, extension services, seed choice and access to credit were selected on the basis of literature reviews.

LnY $=\mathrm{f}($ LnMaize area, LnFarm size, Education, Age, Family size, Training, Membership, Extension, seed choice, Access to credit)

LnProduction $=\alpha 0+\beta \mathrm{i} \mathrm{Xi}+\mathrm{ei}$

Where;

LnProdcution $=$ Maize production (in natural log form)

$\alpha 0=$ Constant

$\beta \mathrm{i}=$ Coefficient

$\mathrm{Xi}=$ Explanatory variables

ei $=$ Error term

Mean comparison of productivity of OP improved and hybrid varieties

An unpaired t test was used to compare the productivity of OP improved and hybrid varieties of maize. Statistical packages for Social Sciences (SPSS) version 25 were used for data analysis.Analysis of the Profitability of Maize Production (OPI or hybrid) Profitability (net income) was estimated by deducting total cost from gross income.

Net Income $=$ Gross Income - Total Cost The gross income was calculated by multiplying the average yield with the price of the given product.

Gross Income $=$ Yield of the Product $*$ Price of the Product

Total cost $=$ Cost on Tractor for tillage + seed cost + Planting cost + Chemical fertilizers cost + Farm Yard Manure cost + Cost on weeding + Cost on Pesticides + Cost on irrigation + Harvesting cost + Threshing cost

Benefit-cost ratio is the ratio of gross return and total variable cost.

$\mathrm{B} / \mathrm{C}$ ratio $=$ Gross return (NRs.) $/$ Total variable cost (NRs.)

\section{Indexing}

The intensity of problems faced by the producers were identified by using five point scaling techniques comparing most serious to no problems at all using score of 1.00, 0.80, 0.60, 0.40, 0.2 , respectively. The formula given below was used to find the index for intensity of production and marketing problem. 
Journal of Agriculture and Natural Resources (2021) 4(1): 130-139

ISSN: 2661-6270 (Print), ISSN: 2661-6289 (Online)

DOI: https://doi.org/10.3126/janr.v4i1.33246

$\mathrm{I}$ prob $=\sum(\mathrm{Si} \mathrm{Fi}) / \mathrm{N}$

Where,

I prob= Index value of intensity of problem

$\sum=$ summation

$\mathrm{Si}=$ Scale value of ith intensity

$\mathrm{Fi}=$ Frequency of ith response

\section{RESULTS AND DISCUSSION}

\section{Descriptive Statistics of Maize Farmers}

Descriptive statistics for the surveyed farmers are presented in Table 1. Among the total respondents, 48 adopted OPI varieties while 32 respondents adopted hybrid varieties of maize. The productivity of Hybrid varieties was 4.18 ton/ha and that of OPI varieties (all combined) was found to be 2.3 ton/ha, which is significant at $1 \%$ level. About $59 \%$ of maize production was affected by Fall Armyworm infestation, OPI varieties were found to be highly susceptible to Fall Armyworm causing infestation in maize production of 33 respondents whereas that of hybrid varieties were found significantly low i.e. infested the maize production of 14 respondents. About $80 \%$ of farmers were the member of agriculture cooperatives and farmer's group with majority being hybrid seed users.

Table 1: Mean comparison of productivity of OP improved and hybrid varieties

\begin{tabular}{|c|c|c|c|c|}
\hline Continuous variables & Total $(\mathrm{N}=80)$ & Hybrid $(\mathrm{N}=32)$ & OPI $(\mathrm{N}=48)$ & $\mathrm{t}$ - value \\
\hline Production (kg) & 3053.14 & 4179.48 & 2302.25 & $-18.524 * * *$ \\
\hline $\begin{array}{l}\text { Age of the household head } \\
\text { (years) }\end{array}$ & 43.96 & 43.84 & 44.04 & 0.087 \\
\hline Family size (Number) & 6.54 & 5.63 & 7.15 & $3.000 * * *$ \\
\hline Farm size (ha) & .75 & .76 & .77 & .395 \\
\hline Maize area (ha) & .38 & .28 & .46 & $3.890 * * *$ \\
\hline Seed cost (NRs./ha) & 4476.36 & 8672.63 & 1678.84 & $-23.620 * * *$ \\
\hline Categorical variables & & & & $\mathrm{Chi}^{2}$ value \\
\hline FAW infestation (Yes=1) & $47(58.8)$ & $14(17.5)$ & $33(41.2)$ & $4.952 * *$ \\
\hline Membership (Yes=1) & $64(80)$ & $30(37.5)$ & $34(42.5)$ & $6.302 * *$ \\
\hline Training $(\mathrm{Yes}=1)$ & $43(53.75)$ & $16(20)$ & $23(28.75)$ & .302 \\
\hline Gender & & & & 0.188 \\
\hline Female & 29 & 12 & 17 & \\
\hline Male & 51 & 20 & 31 & \\
\hline Education & & & & $7.864 * * *$ \\
\hline Illiterate & 3 & 0 & 3 & \\
\hline Literate & 12 & 2 & 10 & \\
\hline Primary & 29 & 8 & 21 & \\
\hline High School & 21 & 10 & 11 & \\
\hline College & 15 & 12 & 3 & \\
\hline Ethnicity & & & & .244 \\
\hline Brahmin/Chhetri & 54 & 22 & 32 & \\
\hline Janajati & 23 & 9 & 14 & \\
\hline Dalit & 3 & 1 & 2 & \\
\hline
\end{tabular}

Note: * significant at $10 \%$ level, ** significant at 5\% and *** significant at $1 \%$

The result showed that hybrid seed users received higher level of education than that of OPI seed users with positive and statistically significant difference at $1 \%$ level. Therefore, the study shows that farmers who were more educated and were member of agriculture cooperative and 
Journal of Agriculture and Natural Resources (2021) 4(1): 130-139

ISSN: 2661-6270 (Print), ISSN: 2661-6289 (Online)

DOI: https://doi.org/10.3126/janr.v4i1.33246

farmer's group adopted high yielding hybrid varieties over OPI varieties in one hectare of land thereby gaining productive knowledge on improving their yields and marketing activities.

In contrast, the average cost of seed was statistically higher of hybrid varieties (NRs. 8672.63/ha) as compared to OPI (NRs. 1678.84/ha). The average farm size of sample farmers was 0.75 ha, and the total maize area allocated for production was 0.38 ha on an average. Both farm size (.77ha) and total maize area (.46 ha) were higher of OPI seed users as compared to the farm size (.76 ha) and total maize area (.28 ha) of Hybrid seed users. The average number of family members of respondents that produced hybrid maize was around 5 and those producing OPI maize was 7 , which was significant at $1 \%$ level of significance. About $23 \%$ of OPI seed users received training, whereas, only $16 \%$ of hybrid seed farmers received training. Regarding household characteristics, there was no statistically significant difference of age, gender and ethnicity between OPI and hybrid seed users. It was observed that lower seed cost along with better taste and storage quality of OPI, most farmers in Sindhupalchok preferred OPI over hybrid maize varieties with larger average farm size and maize area.

\section{Identification of Socioeconomic Factors Influencing Both Hybrid and OPI Maize Output}

This analysis focused on the identification of factors that determine maize production in Sindhupalchok district of Nepal. A multiple regression model was adopted for the analysis. To achieve normality and homogeneity of the error term, the dependent variable production and independent variables total landholdings and maize area were transformed to log form. Based on the analysis, the coefficient of determination (R2) was $91 \%$. This shows that about $91 \%$ of the variance in the maize output was influenced by the explanatory variables included in the model. The mean Variance Inflation Factor (VIF) was 2.7 and none of the variables had VIF higher than 4. It indicates that there was no multicollinearity between independent variables.

The regression coefficient of the maize area was positive and statistically significant related to maize production $(\mathrm{p}<0.05)$. Cultivation of maize in larger areas makes it more economical for farmers to apply inputs and more commercialization of farm. The result corresponds with a study in Nigeria found that maize cultivated area was significant and positively related to maize output (Ajah \& Nmadu, 2012). However, the farm size was negatively signed and not statistically significant. The result was found different to a study in Eastern Terai of Nepal where the farm size was positive but not significant (Adhikari et al., 2018). The coefficient of education of household head was positive and statistically significant at 5\% level. This indicates that for each year increase in the level of education, the production of maize increased significantly. Education enhances the ability of decision makers by enabling the farmers to think critically and use information sources efficiently (Adhikari et al., 2018). Similarly, a study in Tanzania found that education level had statistically impact on maize yield (Justin, 2015). The number of family members was found to be negatively signed and statistically insignificant. However, in a study, it was found that education, family members and farm size significantly influenced the profitability of farm products (Safa, 2005). Age of household head was positive and statistically significant. Training about line sowing method of maize seeds, intercropping with marigold were organized by PMAMP Maize Zone, Sindhupalchok. Hence, training received by the households was positively signed and was statistically significant i.e. if a farmer receives training on appropriate techniques of maize cultivation, there is a corresponding increase in maize production. On the other hand, membership of the farmers to cooperatives and farmer's group was found to be negative and statistically insignificant. Farmer's access to extension services was found to be positive but not statistically significant. The difference between the seed variety preference among farmers was positive and significant 
Journal of Agriculture and Natural Resources (2021) 4(1): 130-139

ISSN: 2661-6270 (Print), ISSN: 2661-6289 (Online)

DOI: https://doi.org/10.3126/janr.v4i1.33246

at $1 \%$ level. This shows that if the respondents were cultivating hybrid seeds, their production was found to be increasing successively. A study in Eastern Nepal also showed that cultivation of hybrid maize is one of the best alternatives to increase the maize production and productivity (Adhikari et al., 2019). Farmer's access to credit was positive and significant at 5\% level which means that if the respondents have access to credit, there is an increase in total production of maize.

Table 2: Regression result of socio-economic factors that influence combined (hybrid and OPI) maize production

\begin{tabular}{llll}
\hline Variables & Coefficient & Pearson's correlation & p-value \\
\hline Maize area (ha) & $2.52^{* *}$ & $-.109(10.9 \%)$ & .01 \\
Farm size (ha) & -.83 & $.171(17 \%)$ & .41 \\
Education (years) & $2.23^{* *}$ & $.814(81.4 \%)$ & .03 \\
Age of HHH (years) & $1.65^{*}$ & $.062(6.2 \%)$ & .10 \\
Family size (no.) & -.05 & $-.304(30.4 \%)$ & .96 \\
Training (1=Yes) & $1.65^{*}$ & $.230(23 \%)$ & .10 \\
Membership (1=Yes) & -1.6 & $.234(23.4 \%)$ & .11 \\
Extension services (1=Yes) & .62 & $.238(23.8 \%)$ & .54 \\
Seed preference (1=Hybrid) & $.12 .88^{* * *}$ & $.922(90 \%)$ & .000 \\
Access to credit (1=Yes) & $2.05^{* *}$ & $.263(26.3 \%)$ & .05 \\
\hline
\end{tabular}

Other statistics

Number of observation $\quad 80$

R-square 0.92

Adjusted R- square $\quad 0.91$

Variance Inflation factor (VIF) 2.7 (mean VIF): no muticollinearity

Notes: ***, **, *indicate statistically significant difference at 1\%, 5\% and $10 \%$ levels, respectively.

\section{Comparative Analysis of Profitability Estimation between OPI and Hybrid Maize Production}

\section{Cost of production}

Farmers expensed highest resources in Farmyard manure for both OPI as well as hybrid maize production which is on average of $30 \%$ of the total cost. The second highest expense was for human labor. It was required for different farm operations such as land preparation, seed planting, fertilizer application, weeding, threshing, transportation, cleaning etc. The average cost of human labor in the production of OPI maize was NRs. 19157.25/ha while that of hybrid maize was NRs. 20794.1/ha. The reason behind the difference between the cost of human labor between OPI and Hybrid maize growers in Sindhupalchok might be because majority of hybrid maize is cultivated in Khet (irrigated low land) which is more or less far from the resident sites of the respondents while majority of OPI maize is cultivated in Bari (up land) which is nearby the respondent's houses. Hence, human labor cost is slightly higher for hybrid maize production than that of OPI due to factors such as distance and increased number of working days. Farmers expensed about $21.22 \%$ on an average tillage cost. In the study area, majority of farmers used tractor $49(61.2 \%)$ for tillage operation followed by oxen plough $17(21.2 \%)$ and then both 14(17.5\%). The tillage cost of hybrid maize was found to be NRs. 20890.03/ha and that of OPI maize was NRs. 19799.96/ha because of distance and long working hour. Farmers performed 2 to 4 tillage operations for maize production. For the reduction in tillage cost, one should focus on resource conservation agriculture (FAO, 2016) (Edralin et al., 2017). The average per hectare cost of hybrid seed was NRs. 8672.63 while that of OPI seed was NRs. 1678.84. From all the surveyed households adopting hybrid maize seed, the majority of seed 
Journal of Agriculture and Natural Resources (2021) 4(1): 130-139

ISSN: 2661-6270 (Print), ISSN: 2661-6289 (Online)

DOI: https://doi.org/10.3126/janr.v4i1.33246

was bought from Agrovet 25(31.2\%) followed by Cooperative 7(8.8\%). No amount of hybrid seeds were received from neither government subsidy nor own harvest which is the major reason behind inclined price of hybrid seeds. On the other hand, $5(6.2 \%)$ respondents received OPI seeds from their own harvest, 21 (26.2\%) respondents bought OPI seeds from Agrovet, 13 (16.2\%) bought from cooperative and $9(11.2 \%)$ received the seed from government subsidy. Almost all the farmers used chemical fertilizers such as Urea, DAP (Di-Ammonium Phosphate), Potash. Some of the hybrid seed using farmers also used micronutrients like calcium, boron and sulfur for production. On average, farmers expensed about NRs. 4951.88/ha $(5.16 \%)$ of total cost for inorganic fertilizers. Majority of farmers used hands for threshing maize grain. Only few households used mechanical thresher. The average threshing cost per hectare was about NRs. 13646.5 i.e. $14.23 \%$ of the total cost. Similarly, few farmers applied pesticide to their crops due to the significant impact of Fall Armyworm, which constituted about an average of $0.54 \%$ of the total variable cost of production.

Table 3: Cost, return and benefit cost analysis of OPI and hybrid maize production per hectare

\begin{tabular}{|c|c|c|c|c|c|c|}
\hline Variable & $\begin{array}{l}\text { Overall } \\
\text { Mean }\end{array}$ & OPI $(n=48)$ & $\begin{array}{l}\text { Hybrid } \\
(\mathrm{n}=32)\end{array}$ & $\begin{array}{l}\text { Mean } \\
\text { difference }\end{array}$ & T value & $\mathrm{P}$ value \\
\hline $\begin{array}{l}\text { Area under } \\
\text { maize (ha) }\end{array}$ & 0.37 & .46 & .28 & .18 & $3.873^{* * *}$ & .000 \\
\hline $\begin{array}{l}\text { Cost of seed } \\
\text { (NRs./ha) }\end{array}$ & 5175.74 & 1678.84 & 8672.63 & -6993.79 & $-23.62^{* * *}$ & .000 \\
\hline $\begin{array}{l}\text { Cost of FYM } \\
\text { (NRs./ha) }\end{array}$ & 29665 & 29392.48 & 29937.5 & -545.02 & -.697 & .488 \\
\hline $\begin{array}{l}\text { Fertilizer cost } \\
\text { (NRs./ha) }\end{array}$ & 4951.88 & 4638.44 & 5265.31 & -626.88 & $-2.08^{* *}$ & .041 \\
\hline $\begin{array}{l}\text { Tillage cost } \\
\text { (NRs./ha) }\end{array}$ & 20345 & 19799.96 & 20890.03 & -1090.07 & -1.102 & .274 \\
\hline $\begin{array}{l}\text { Threshing cost } \\
\text { (NRs./ha) }\end{array}$ & 13646.5 & 13217.83 & 14075.1 & -857.26 & -.986 & .327 \\
\hline $\begin{array}{ll}\text { Labor } & \text { cost } \\
\text { (NRs./ha) } & \end{array}$ & 19975.7 & 19157.25 & 20794.1 & -1636.86 & -2.723 & 998 \\
\hline $\begin{array}{l}\text { Transportation } \\
\text { cost (NRs./ha) }\end{array}$ & 2180.54 & 2058.82 & 2302.25 & -152.34 & $-1.587^{*}$ & .118 \\
\hline $\begin{array}{l}\text { Total cost of } \\
\text { cultivation } \\
\text { (NRs./ha) }\end{array}$ & 95894.7 & 89943.62 & 101845.84 & -11902.22 & $-6.310^{* * *}$ & .000 \\
\hline $\begin{array}{l}\text { Total Return } \\
\text { (NRs./ha) }\end{array}$ & 135562 & 110214.35 & 160910.1 & -50695.73 & $-12.516^{* * *}$ & .000 \\
\hline $\mathrm{B}: \mathrm{C}$ & 1.41 & 1.23 & 1.59 & -.36 & $-8.029^{* * *}$ & .000 \\
\hline
\end{tabular}

\section{Comparative Analysis of the returns between OPI and Hybrid Maize Production}

Table no. 4 revealed the gross margin analysis from maize production in Sindhupalchok district. Farmers in the study area were involved in maize farming on an average of 0.38 ha of land with per hectare production as $3053.14 \mathrm{~kg}$. The average farm gate price of hybrid maize was NRs. $37.5 / \mathrm{kg}$ while that of OPI maize was NRs. $46.88 / \mathrm{kg}$. The difference in the price of two varieties is due to higher longevity of OPI maize than that of hybrid maize. According to the farmers, OPI maize can be stored and well eaten for more than a year whereas hybrid maize starts to shrink and degrade after 3 months of storage. The average per hectare price of maize by-product is NRs.3053.14. The average gross return of hybrid maize is NRs. 160910.08 while that of OPI maize is NRs. 110214.35. Likewise, the total cost of production of hybrid maize was NRs. 126736.18 while that of OPI maize was NRs. 89031.1/ha. The average gross margin 
Journal of Agriculture and Natural Resources (2021) 4(1): 130-139

ISSN: 2661-6270 (Print), ISSN: 2661-6289 (Online)

DOI: https://doi.org/10.3126/janr.v4i1.33246

of hybrid maize and OPI maize are NRs. 59064.24 and NRs. 20270.73 respectively. The average BCR of hybrid maize was found to be 1.59 and that of OPI was found to be 1.23. This implies that although the cost of cultivation is lower and farm gate price is higher for OPI varieties, farmers are deviated towards producing hybrid varieties because of its higher yield and slight variation in terms of increased profit in comparison to OPI. Overall, it was found that maize production in general was highly profitable; therefore it has a significant contribution to the income of the farmers.

Table 4: Average return in maize production

\begin{tabular}{llll}
\hline Measuring criteria & $\begin{array}{l}\text { Average value } \\
\text { Hybrid }\end{array}$ & OPI & Both \\
\hline Main product value (NRs./ha) & 156730.59 & 107912.10 & 127439.5 \\
By-product value (NRs./ha) & 4179.48 & 2302.25 & 3053.14 \\
Gross return (NRs/ha) & 160910.08 & 110214.35 & 130492.64 \\
Total cost (NRs/ha) & 101845.84 & 89943.62 & 95894.7 \\
Gross Margin (NRs/ha) & 59064.24 & 20270.73 & 34597.94 \\
BCR & 1.59 & 1.23 & 1.41 \\
\hline
\end{tabular}

Problems associated with maize production:

When questioned about the problems associated with maize production from a focused group discussion among the respondents, five major problems were identified for the study. From the survey conducted among the maize growers, lack of availability of quality seeds and fertilizers was ranked as the major problem followed by incidence of disease and pests. Similarly, lack of advanced technology and training, wild animal attack and lack of proper interaction between farmers and extension service providers were third, fourth and fifth problems respectively as per farmer's ranking (Table 5). A study showed that the quality of seed and infestation of disease and pests significantly affected the yield (Paudyal et al., 2001). In addition, it was reported that the adoption of maize seed production, increment in maize production and income are assisted by the availability of technical assistance by the extension service providers (Hintze et al., 2003). A study showed that maize production can be improved or increased through adequate nutrient management practices (Adhikary et al., 2020). (Subedi et al., 2018) reported that farmers should be provided the environment for interaction and discussion on various problems related to crop production. A study showed that farmers who joined the Farmer's Field School (FFS) were more likely able to identify and prioritize the field problems and solutions by themselves (Jha \& Regmi, 2009).

Table 5: Problems associated with maize production

\begin{tabular}{|c|c|c|c|c|c|c|c|}
\hline Problems & Most serious & Serious & Moderate & Less serious & Least serious & Index value & Rank \\
\hline wild animal attack & 11 & 21 & 1 & 15 & 32 & 0.51 & IV \\
\hline $\begin{array}{l}\text { lack of quality } \\
\text { seed and fertilizer }\end{array}$ & 35 & 14 & 22 & 5 & 4 & 0.78 & I \\
\hline $\begin{array}{l}\text { lack of advanced } \\
\text { technology and } \\
\text { training }\end{array}$ & 3 & 28 & 27 & 22 & 0 & 0.63 & III \\
\hline $\begin{array}{l}\text { lack of proper } \\
\text { interaction } \\
\text { between farmers } \\
\text { and extension } \\
\text { service provider }\end{array}$ & 0 & 3 & 26 & 20 & 31 & 0.40 & V \\
\hline $\begin{array}{l}\text { incidence of } \\
\text { disease and pests }\end{array}$ & 31 & 14 & 5 & 17 & 13 & 0.68 & II \\
\hline
\end{tabular}


Journal of Agriculture and Natural Resources (2021) 4(1): 130-139

ISSN: 2661-6270 (Print), ISSN: 2661-6289 (Online)

DOI: https://doi.org/10.3126/janr.v4i1.33246

\section{CONCLUSION}

The multiple regression model showed that maize area, education of household head, access to credit and training were the socioeconomic factors that influenced maize output in the study area. Hybrid varieties with BCR 1.59 produced two times higher profitability than OP improved with BCR 1.23. Moreover, the difference between the productivity of OP improved and hybrid maize varieties was found to be highly significant in this study which concluded that hybrids are significantly superior to OP improved varieties in terms of productivity. Therefore, government institutions should orient their efforts in developing high yielding hybrid varieties in Nepal in order to increase maize productivity. Furthermore, appropriate extension services are needed for the adoption of developed hybrids. Lack of quality seeds and fertilizer was the major problem followed by incidence of disease and pest. Despite the cost of seed is higher for hybrid varieties, they are found to be less susceptible to Fall Armyworm and other destructive pests. The finding suggests that a higher level of education and training on hybrid maize farming could help to better production. Higher yield could be achieved through commercialization and land integration concept in maize farming as suggested by the Senior Plant Protection Officer of PMAMP Maize Zone, Sindhupalchok, Mr. Prakash Paudel. Farmers expensed more than $20 \%$ in labor cost and tillage cost each. The study recommends the government to promote mechanization and introduce cost efficient technology of maize farming in the mid hill regions of Nepal. Farmers expensed more than $8 \%$ of the total cost in hybrid seeds while less than $2 \%$ in OPI seeds. Government should focus on the development of affordable hybrid maize varieties or high yielding OPI and its extension to substitute for better productivity.

\section{ACKNOWLEDGEMENT}

The author would like to thank Prime Minister Agriculture Modernization Project, Maize zone, PIU-Sindhupalchok and Agriculture and Forestry University for financial support and platform to carry out this study. The authors extend sincere gratitude to the farmers of Sindhupalchok.

\section{Author's Contribution}

G. Tiwari designed the research plan. G. Tiwari, C. K.C., and A. Shrestha collected the data; G. Tiwari designed a data entry template in MS excel and entered the data. G. Tiwari and C. K.C. analyzed the data and prepared the manuscript. P. Thapa provided comments and feedback to finalize this manuscript. Final form of manuscript was approved by all authors.

\section{Conflict of Interest}

The authors declare that there is no conflict of interest with present publication.

\section{REFERENCES}

Adhikari, S. P., Shrestha, K. P., \& Shrestha, S. R. (2018). Analysis of Socio-economic Factors and Profitability of Hybrid Maize Production in Eastern Terai of Nepal. South Asian Journal of Social Studies and Economics, 1-7.

Adhikary, B. H., Baral, B. R., \& Shrestha, J. (2020). Productivity of winter maize as affected by varieties and fertilizer levels. International Journal of Applied Biology, 4(1), 85-93. DOI: https://doi.org/10.20956/ijab.v4i1.10192

Ajah, J., \& Nmadu, J. N. (2012). Socio-economic factors influencing the output of small-scale maize farmers in Abuja, Nigeria. Kasetsart Journal - Social Sciences, 33(2), 333-341. 
Journal of Agriculture and Natural Resources (2021) 4(1): 130-139

ISSN: 2661-6270 (Print), ISSN: 2661-6289 (Online)

DOI: https://doi.org/10.3126/janr.v4i1.33246

Dhakal, S. C., Regmi, P. P., Thapa, R. B., Sah, S. K., \& Khatri-Chhetri, D. B. (2015). Productivity and profitability of maize-pumpkin mix cropping in Chitwan, Nepal. Journal of Maize Research and Development, 1(1), 112-122. DOI: https://doi.org/10.3126/jmrd.v1i1.14249

Edralin, D. A., Sigua, G. C., Reyes, M. R., Mulvaney, M. J., \& Andrews, S. S. (2017). Conservation agriculture improves yield and reduces weeding activity in sandy soils of Cambodia. Agronomy for Sustainable Development, 37(5), 52. DOI: https://doi.org/10.1007/s13593-017-0461-7

FAO. (2016). the Economics of Conservation Agriculture. Biological Conservation, 2(2), 4758. Retrieved from https://www.fsnnetwork.org/sites/default/files/economicconservation.pdf

Hintze, L. H., Renkow, M., \& Sain, G. (2003). Variety characteristics and maize adoption in Honduras. Agricultural Economics, 29(3), 307-317. DOI: https://doi.org/10.1016/S01695150(03)00058-6

Jha, R. K., \& Regmi, A. P. (2009). Pesticide productivity and vegetable farming in Nepal. Environmental Valuation: In South Asia, 43, 115-140. DOI: https://doi.org/10.1017/CBO9780511843938.007

Justin, K. U. (2015). Factors influencing maize crop production at household levels: A case of Rukwa Region in the southern highlands of Tanzania. African Journal of Agricultural Research, 10(10), 1097-1106. DOI: https://doi.org/10.5897/ajar2014.9262

MOALD. (2017). Statistical Information in Nepalese Agriculture. Ministry of Agriculture and Livestock, 290. Retrieved from https://nepalindata.com/resource/statistical-informationnepalese-agriculture-207374-201617/

Paudyal, K. R., Ransom, J. K., Rajbhandari, N. P., Adhikari, K., Gerpacio, R. V., \& Pingali, P. L. (2001). Maize in Nepal: production systems, constraints, and priorities for research. Cimmyt

Safa, M. S. (2005). Socio-economic factors affecting the income of small-scale agroforestry farms in hill country areas in Yemen: A comparison of OLS and WLS determinants. Small-Scale Forest Economics, Management and Policy, 4(1), 117-134. DOI: https://doi.org/10.1007/s11842-005-0008-7

Sapkota, D., \& Pokhrel, S. (2013). Community based maize seed production in the hills and mountains of Nepal: A review. Agronomy Journal of Nepal, 1, 107-112. DOI: https://doi.org/10.3126/ajn.v1i0.7550

Subedi, S., Ghimire, Y. N., \& Devkota, D. (2018). Socio-economic assessment on maize production and adoption of open pollinated improved varieties in Dang, Nepal. Journal of Maize Research and Development, 3(1), 17-27. DOI: https://doi.org/10.3126/jmrd.v3i1.18916

Upadhyay, N., Ghimire, Y. N., Sharma, B., Acharya, Y., Gairhe, S., \& Sapkota, S. (2018). Factors Affecting Adoption of Maize Varieties in Nepal. Journal of the Institute of Agriculture and Animal Science, 35(1), 39-45. DOI: https://doi.org/10.3126/jiaas.v35i1.22512 